\title{
Fuzzy-Neural based Cost Effective Handover Prediction Technique for 5G-IoT networks
}

\author{
Rashad.t.s., A.Ch. Sudhir
}

\begin{abstract}
Most of the existing works related to handover prediction in $5 G$ networks, depends on huge mobility patterns collected over several periods of time, which will be tedious and complex to classify and analyze these patterns to predict the future locations of mobile users. Hence the main objective is to design a HO prediction technique which accurately predicts the next cell location with least amount of mobility history or patterns. In this paper, we design handoff prediction and target network selection scheme for 5G-IoT networks. For VHO triggering condition, Multi-layer Feed Forward Network (MFNN) is applied which will predict the user mobility based on distance, RSS, mobile speed and direction parameters. For target cell selection, Fuzzy decision model is applied based on the network level metrics such as traffic load, handover latency, battery power and user level metrics such as security and cost. The proposed approach will be implemented in NS3 and the performance is measured in terms of network throughput, handoff delay, handoff cost and prediction accuracy.

Keywords: 5G; IoT; Fuzzy; Cost; Prediction
\end{abstract}

\section{INTRODUCTION}

Communication is so essential for us in day-to-day life. $5^{\text {th }}$ generation $(5 \mathrm{G})$ networking stands for a wireless broadband technology, connecting all sort of devices. When compared to $4 \mathrm{G}$ networks, 5G provides Maximumer speed and coverage [1]. It utilizes all latest technologies with Maximum antenna frequency. It can handle larger volumes of mobile data than $4 \mathrm{G}[2] .5 \mathrm{G}$ network consists of tiny cells to meet the growing demands of mobile users and to provide connectivity at any time from any place [3]. It enables mobile broadband technology to cope up with IoT applications [3]. Recently, there has been a rapid development of Internet of Things (IoT) in the diverse sectors. By using IoT, any mobile device can connect to the Internet. The IoT devices can be connected to a $5 \mathrm{G}$ network. But to achieve the required quality of service $(\mathrm{QoS})$, they need to be connected to the Internet. Due to the limited resource constraints of IoT devices, existing mobility management technique cannot be applied for the IoT networks [4].

5G networks have both handover (HO) and location management (LM) functions. While HO concentrates on cell switching the LM concentrates on location tracking. HO enables User Equipments (UEs) to seamlessly move within the coverage area of the network. The HO mechanism involves reassigning an ongoing session handled by one cell into another [5][6]. To Minimumimize the HO latency, signalling cost and call blocking rate, HO prediction is the mostly used approach [7].

\section{PROBLEM IDENTIFICATION AND OBJECTIVES}

In a Minimum-cost mobility prediction approach [7], a $\mathrm{HO}$ cost is derived in terms of call dropping, latency, signalling cost and resource consumption. Finally, the prediction is made such that the $\mathrm{HO}$ cost with prediction should be less than the $\mathrm{HO}$ cost without prediction. But the prediction was done using MLP techniques with time and location as inputs which may not give accurate results, if the user does not belong to a specific group.

In data driven $\mathrm{HO}$ optimization [8], weighted average of various mobility problems is deterMinimumed. Then MLP techniques are applied for estimating KPI and the HO is performed such that KPI is Minimumimized.

Most of the existing works related to handover prediction in 5G networks, depends on huge mobility patterns collected over several periods of time, which will be tedious and complex to classify and analyze these patterns to predict the future locations of mobile users. Moreover, the probability of handoff was estimated only from the received signal strength (RSS) indicators, which may not give the exact duration of the user in the current cell.

Hence the main objective is to design a $\mathrm{HO}$ prediction technique which accurately predicts the next cell location with least amount of mobility history or patterns.

\section{PROPOSED SOLUTION}

\section{A. Overview}

In this paper, we design handoff prediction and target network selection scheme for 5G-IoT networks. For VHO triggering condition, Multi-layer Feed Forward Network (MFNN) is applied which will predict the user mobility based on distance, RSS, mobile speed and direction parameters. For target cell selection, Fuzzy decision model is applied based on the network level metrics such as traffic load, handover latency, battery power and user level metrics such as security and cost. The proposed approach will be implemented in NS3 and the performance is measured in terms of network throughput, handoff delay, handoff cost and prediction accuracy.

. Revised Manuscript Received on December 13, 2019.

* Correspondence Author

Rashad T.S., Scientist 'F' RCI, DRDO, Hyderabad Email: Rashad ts@yahoo.com

A.CH. Sudhir, Asst. Professor, Dept. of Electronics and Communication Engg .GITAM(Deemed to be University) Email: sudhir.ach1@gmail.com 


\section{B. Estimation of Metrics}

The parameters are categorized as network level and user level.

Network level metrics includes the folMinimuming parameters:

- $\quad$ Received Signal Strength (RSS)

- Throughput

- Traffic Load

- Latency

- Residual Energy

The user level metrics includes the folMinimuming metrics

- Security

- Cost

\section{a. RSS}

RSSI is the ratio of the received power $\left(\mathrm{P}_{\mathrm{rx}}\right)$ to the reference power $\left(\mathrm{P}_{\mathrm{r}}\right)$, given by

RSSI $=10 . \log \frac{P_{r x}}{P_{r e f}}(\mathrm{dBm})$

\section{b. Throughput}

It is given by the aggregate of successfully received data at the receiver, in terms of bits/second.

\section{c. Traffic Load}

Load (L(i)) refers to the traffic density of the node which is the sum of traffic queue of node and the traffic queue of all its neighbors.

$$
\mathrm{L}(\mathrm{i})=\sum_{\forall j \in N(i)} l_{i}
$$

where $\mathrm{N}(\mathrm{i})=$ neighbourhood of the node

$l_{i}=$ size of the traffic queue

$\mathrm{L}_{\mathrm{i}}=$ sum of traffic queue of all neighbours of node $\mathrm{i}$

\section{d. Latency}

Latency $(\mathrm{L})$ is the Minimum time for transmitting a message from the node to the farthest node.

\section{e. Residual Energy}

The total energy consumption of the transmitter is given by the folMinimuming eq.

$E_{t x}=E_{e} \cdot x+E_{a} \cdot x \cdot d^{2}$

where $E_{e}$ is electronics energy, $E_{a}$ is the amplifier energy, $x$ is the size of transmitted message, $d$ is the distance.

The aggregated energy consumption at the destination is given by

$\mathrm{E}_{\mathrm{rx}}=\mathrm{E}_{\mathrm{e}} \cdot \mathrm{X}$

The remaining energy of a node $\left(\mathrm{E}_{\mathrm{res}}\right)$ is then given by

$\mathrm{E}_{\mathrm{res}}=\left[\mathrm{E}_{\mathrm{i}}-\left(\mathrm{E}_{\mathrm{tx}}+\mathrm{E}_{\mathrm{rx}}\right)\right]$

\section{f. Cost}

The handover cost is defined as folMinimums:

$$
\sum_{0}^{\infty} k r_{k}+\frac{r_{\rho}}{\left(1-r_{\rho}\right)^{2}}
$$

\section{$\mathrm{r} \rho=$ probability density function \\ C. User Mobility Prediction}

For VHO triggering condition, Multi-layer Feed Forward Network (MFNN) is applied which will predict the user mobility based on distance, RSS, mobile speed and direction parameters [9][11].

The architecture of feed forward neural network:

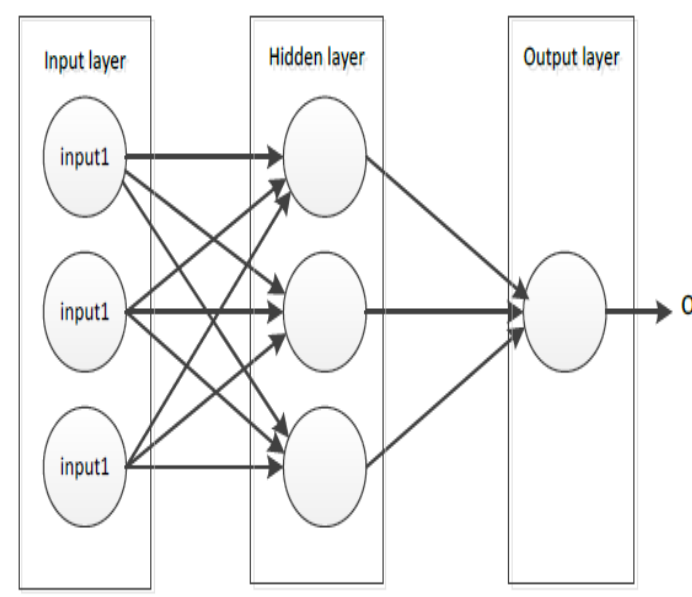

Fig.1. A feed forward neural network is used to predict the future location of a node.

The first layer represents the input layer with 3 nodes. The second layer represents hidden layer which also contains three nodes. The third layer is called output layer. In MFNN, data fMinimum exists between input and output layers, through the hidden layers.

Every node in a layer is interconnected with all the nodes in the previous layer. Each connection may have a different weight.

The output of the neural network $(\mathrm{O})$ is computed as folMinimum:

$\mathrm{O}=\mathrm{f}\left[\left[\sum_{i=1}^{n} q_{i} r_{i}\right]\right.$

Where $n$ is the number of nodes in the hidden layer, $\mathrm{q}_{i}$ is the weight of the link between the node in the hidden layer and the node in the output, $\mathrm{r}_{i}$ denotes to the output of the node in the hidden layer

$f$ is an activation function of the node.

In our technique, the mobility pattern $\left(\mathrm{MP}_{\mathrm{i}}\right)$ is defined in terms of distance (A), RSS (B), mobile speed (C) and direction parameters $(\mathrm{D}\{\mathrm{x}, \mathrm{y}\})$ (estimated in section 3.2). It is represented as folMinimums:

$\mathrm{MP}_{\mathrm{i}}=\left\{\mathrm{A}_{\mathrm{i}}, \mathrm{B}_{\mathrm{i}}, \mathrm{C}_{\mathrm{i}}, \mathrm{D}\right)$

The training data is formed from the set of sub-patterns extracted from MP. The patterns are divided into $n-m$ sub-patterns (SP) with size $\mathrm{m}<\mathrm{n}$. The output will be the user's next location.

For example, if $\left\{\mathrm{SP}_{1}, \mathrm{SP}_{2}, \ldots \mathrm{SP}_{\mathrm{k}}\right\}$ is the sub-pattern, then $\mathrm{SP}_{\mathrm{m}+1}$ is the required output. Here $\mathrm{m}$ is the prediction order, which is fixed based on the volume of stored mobility patterns. 
Table I shows the training data for $\mathrm{MP}_{10}$ and $\mathrm{m}=4$.

Table I: training data

\begin{tabular}{|l|l|l|l|l|l|}
\hline \multicolumn{7}{|c|}{ Table-1 Data Format of IIFN } \\
\hline$S P$ & Inputl & Input2 & Input3 & Input4 & Ouput \\
\hline 1 & $S P_{1}$ & $S P_{2}$ & $S P_{3}$ & $S P_{4}$ & $S P_{5}$ \\
\hline 2 & $S P_{2}$ & $S P_{3}$ & $S P_{4}$ & $S P_{5}$ & $S P_{6}$ \\
\hline 3 & $S P_{3}$ & $S P_{4}$ & $S P_{5}$ & $S P_{6}$ & $S P_{7}$ \\
\hline 4 & $S P_{4}$ & $S P_{5}$ & $S P_{6}$ & $S P_{7}$ & $S P_{8}$ \\
\hline 5 & $S P_{5}$ & $S P_{6}$ & $S P_{7}$ & $S P_{8}$ & $S P_{9}$ \\
\hline 6 & $S P_{6}$ & $S P_{7}$ & $S P_{8}$ & $S P_{9}$ & $S P_{10}$ \\
\hline
\end{tabular}

Thus the future location of mobile user is predicted using MFNN.

\section{Fuzzy Based Target Cell Selection}

For target cell selection, Fuzzy decision model is applied based on the network level metrics such as traffic load, handover latency, battery power and user level metrics such as security and cost.

Fuzzy logic involves fuzzfication, rule evaluation, rule aggregation and defuzzification. Fuzzification is the process of converting the input variables into corresponding Fuzzy sets. Here the input variables are traffic load (L), handover latency $(H)$, Residual energy $\left(E_{\text {res }}\right)$, security $(S)$ and cost $(C)$. Each input variable has two values namely Maximum and Minimum.

The fuzzy logic model is illustrated in Figure 2.
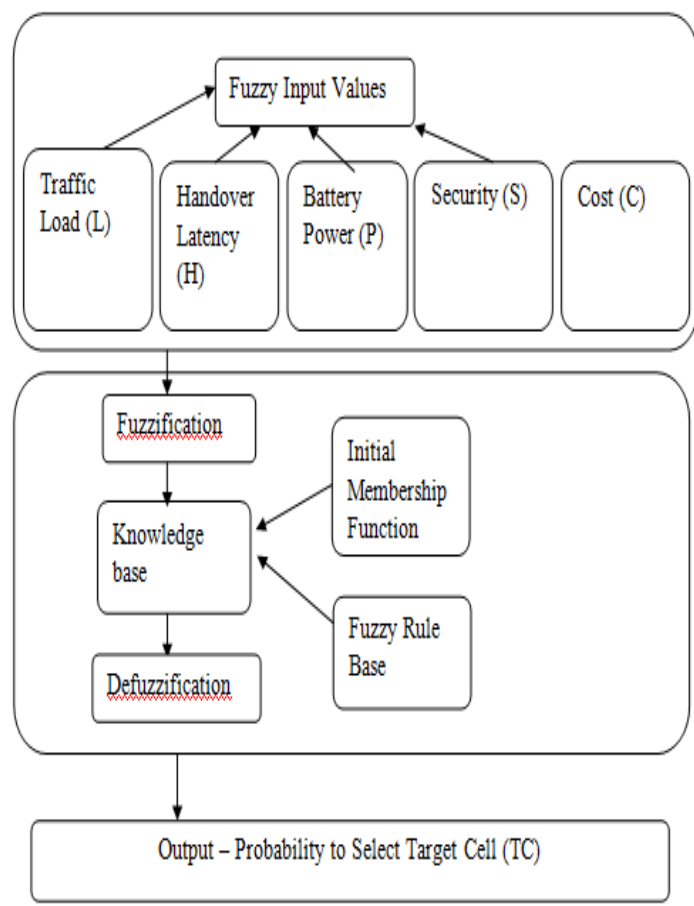

Fig.2 Fuzzy logic model

The fuzzy sets and membership functions for the input and output variables are demonstrated in Figure 3, 4, 5, 6 and 7.

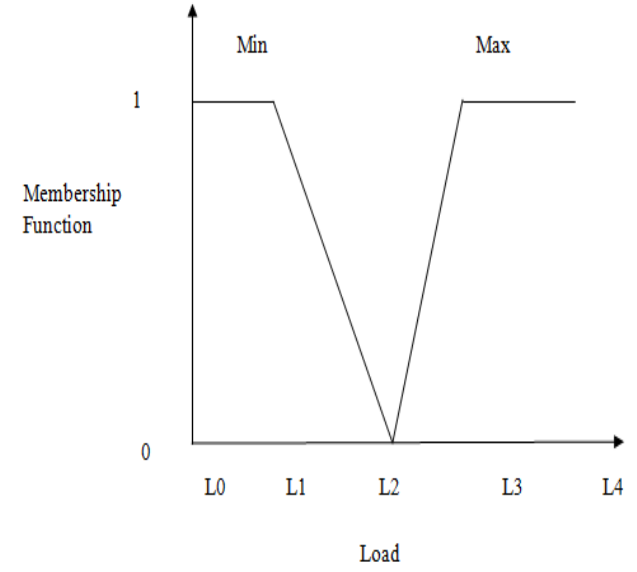

Fig.3. Fuzzy set for Load

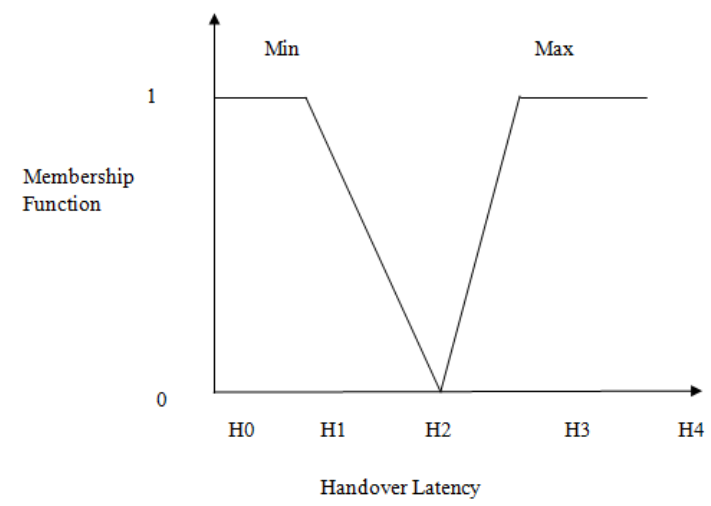

Fig 4. Fuzzy set for Handover Latency

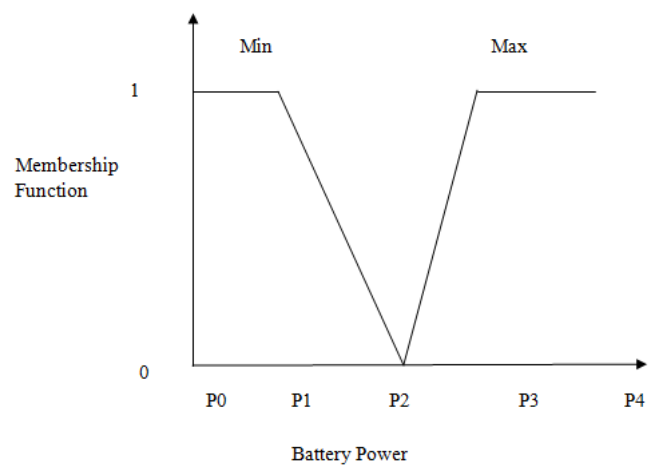

Fig.5. Fuzzy set for Battery Power

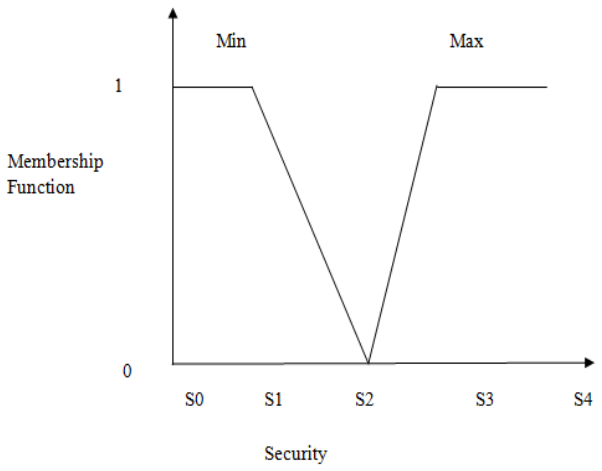

Fig.6. Fuzzy set for Security 


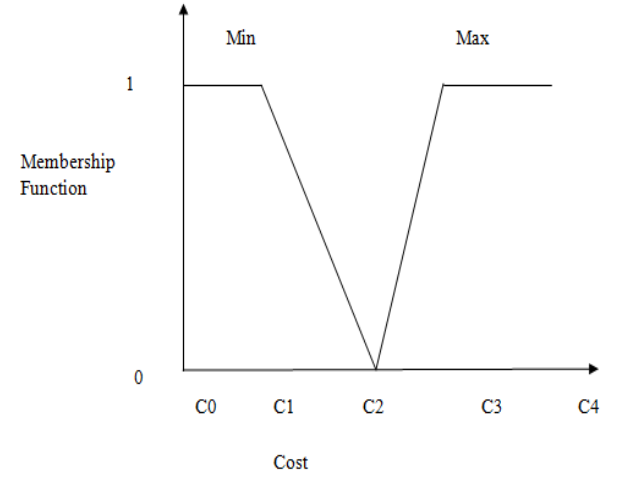

Fig. 7. Fuzzy set for HO Cost

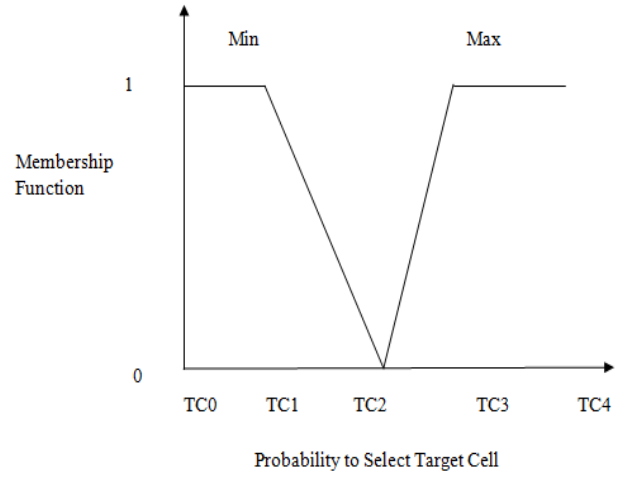

Fig. 8. Fuzzy set for Probability of Target Cell (TC)

The fuzzy sets are defined with the rules as per Table II.

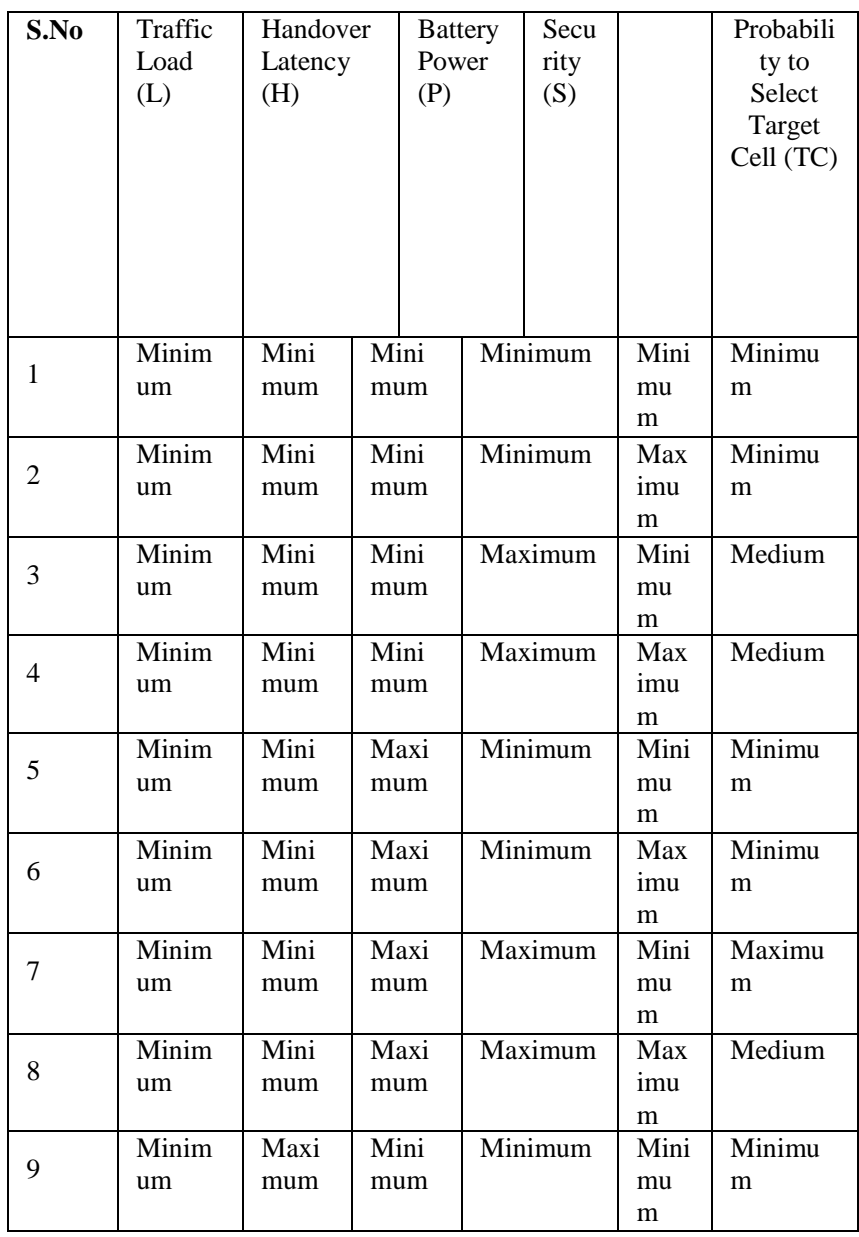

\begin{tabular}{|c|c|c|c|c|c|c|c|}
\hline S.No & $\begin{array}{l}\text { Traffic } \\
\text { Load } \\
\text { (L) }\end{array}$ & \multicolumn{2}{|c|}{$\begin{array}{l}\text { Handover } \\
\text { Latency } \\
(\mathrm{H})\end{array}$} & $\begin{array}{l}\text { Battery } \\
\text { Power } \\
\text { (P) }\end{array}$ & $\begin{array}{l}\text { Secu } \\
\text { rity } \\
(\mathrm{S})\end{array}$ & & $\begin{array}{c}\text { Probabili } \\
\text { ty to } \\
\text { Select } \\
\text { Target } \\
\text { Cell (TC) }\end{array}$ \\
\hline 10 & $\begin{array}{l}\text { Minim } \\
\text { um }\end{array}$ & $\begin{array}{l}\text { Maxi } \\
\text { mum }\end{array}$ & $\begin{array}{l}\text { Mini } \\
\text { mum }\end{array}$ & & imum & $\begin{array}{l}\text { Max } \\
\text { imu } \\
\mathrm{m}\end{array}$ & $\begin{array}{l}\text { Minimu } \\
\mathrm{m}\end{array}$ \\
\hline 11 & $\begin{array}{l}\text { Minim } \\
\text { um }\end{array}$ & $\begin{array}{l}\text { Maxi } \\
\text { mum }\end{array}$ & $\begin{array}{l}\text { Mini } \\
\text { mum }\end{array}$ & & kimum & $\begin{array}{l}\text { Mini } \\
\text { mu } \\
\mathrm{m}\end{array}$ & $\begin{array}{l}\text { Minimu } \\
\mathrm{m}\end{array}$ \\
\hline 12 & $\begin{array}{l}\text { Minim } \\
\text { um }\end{array}$ & $\begin{array}{l}\text { Maxi } \\
\text { mum }\end{array}$ & $\begin{array}{l}\text { Mini } \\
\text { mum }\end{array}$ & & ximum & $\begin{array}{l}\text { Max } \\
\text { imu } \\
\text { m }\end{array}$ & Medium \\
\hline 13 & $\begin{array}{l}\text { Minim } \\
\text { um }\end{array}$ & $\begin{array}{l}\text { Maxi } \\
\text { mum }\end{array}$ & $\begin{array}{l}\text { Maxi } \\
\text { mum }\end{array}$ & & imum & $\begin{array}{l}\text { Mini } \\
\text { mu } \\
\text { m }\end{array}$ & $\begin{array}{l}\text { Minimu } \\
\mathrm{m}\end{array}$ \\
\hline 14 & $\begin{array}{l}\text { Minim } \\
\text { um }\end{array}$ & $\begin{array}{l}\text { Maxi } \\
\text { mum }\end{array}$ & $\begin{array}{l}\text { Maxi } \\
\text { mum }\end{array}$ & & imum & $\begin{array}{l}\text { Max } \\
\text { imu } \\
\text { m }\end{array}$ & Medium \\
\hline 15 & $\begin{array}{l}\text { Minim } \\
\text { um }\end{array}$ & $\begin{array}{l}\text { Maxi } \\
\text { mum }\end{array}$ & $\begin{array}{l}\text { Maxi } \\
\text { mum }\end{array}$ & & ximum & $\begin{array}{l}\text { Mini } \\
\mathrm{mu} \\
\mathrm{m}\end{array}$ & $\begin{array}{l}\text { Minimu } \\
\mathrm{m}\end{array}$ \\
\hline 16 & $\begin{array}{l}\text { Minim } \\
\text { um }\end{array}$ & $\begin{array}{l}\text { Maxi } \\
\text { mum }\end{array}$ & $\begin{array}{l}\text { Maxi } \\
\text { mum }\end{array}$ & & rimum & $\begin{array}{l}\text { Max } \\
\text { imu } \\
\text { m }\end{array}$ & Medium \\
\hline 17 & $\begin{array}{l}\text { Maxim } \\
\text { um }\end{array}$ & $\begin{array}{l}\text { Mini } \\
\text { mum }\end{array}$ & $\begin{array}{l}\text { Mini } \\
\text { mum }\end{array}$ & & imum & $\begin{array}{l}\text { Mini } \\
\text { mu } \\
\mathrm{m}\end{array}$ & $\begin{array}{l}\text { Minimu } \\
\mathrm{m}\end{array}$ \\
\hline 18 & $\begin{array}{l}\text { Maxim } \\
\text { um }\end{array}$ & $\begin{array}{l}\text { Mini } \\
\text { mum }\end{array}$ & $\begin{array}{l}\text { Mini } \\
\text { mum }\end{array}$ & & imum & $\begin{array}{l}\text { Max } \\
\text { imu } \\
\text { m }\end{array}$ & $\begin{array}{l}\text { Minimu } \\
\mathrm{m}\end{array}$ \\
\hline 19 & $\begin{array}{l}\text { Maxim } \\
\text { um }\end{array}$ & $\begin{array}{l}\text { Mini } \\
\text { mum }\end{array}$ & $\begin{array}{l}\text { Mini } \\
\text { mum }\end{array}$ & & ximum & $\begin{array}{l}\text { Mini } \\
\text { mu } \\
\mathrm{m}\end{array}$ & $\begin{array}{l}\text { Minimu } \\
\mathrm{m}\end{array}$ \\
\hline 20 & $\begin{array}{l}\text { Maxim } \\
\text { um }\end{array}$ & $\begin{array}{l}\text { Mini } \\
\text { mum }\end{array}$ & $\begin{array}{l}\text { Mini } \\
\text { mum }\end{array}$ & & ximum & $\begin{array}{l}\text { Max } \\
\text { imu } \\
\mathrm{m}\end{array}$ & Medium \\
\hline 21 & $\begin{array}{l}\text { Maxim } \\
\text { um }\end{array}$ & $\begin{array}{l}\text { Mini } \\
\text { mum }\end{array}$ & $\begin{array}{l}\text { Maxi } \\
\text { mum }\end{array}$ & & imum & $\begin{array}{l}\text { Mini } \\
\text { mu } \\
\text { m }\end{array}$ & $\begin{array}{l}\text { Minimu } \\
\mathrm{m}\end{array}$ \\
\hline 22 & $\begin{array}{l}\text { Maxim } \\
\text { um }\end{array}$ & $\begin{array}{l}\text { Mini } \\
\text { mum }\end{array}$ & $\begin{array}{l}\text { Maxi } \\
\text { mum }\end{array}$ & & imum & $\begin{array}{l}\text { Max } \\
\text { imu } \\
m\end{array}$ & $\begin{array}{l}\text { Minimu } \\
\mathrm{m}\end{array}$ \\
\hline 23 & $\begin{array}{l}\text { Maxim } \\
\text { um }\end{array}$ & $\begin{array}{l}\text { Mini } \\
\text { mum }\end{array}$ & $\begin{array}{l}\text { Maxi } \\
\text { mum }\end{array}$ & & kimum & $\begin{array}{l}\text { Mini } \\
\text { mu } \\
\mathrm{m}\end{array}$ & $\begin{array}{l}\text { Minimu } \\
\mathrm{m}\end{array}$ \\
\hline 24 & $\begin{array}{l}\text { Maxim } \\
\text { um }\end{array}$ & $\begin{array}{l}\text { Mini } \\
\text { mum }\end{array}$ & $\begin{array}{l}\text { Maxi } \\
\text { mum }\end{array}$ & & ximum & $\begin{array}{l}\text { Max } \\
\text { imu } \\
m\end{array}$ & $\begin{array}{l}\text { Minimu } \\
\mathrm{m}\end{array}$ \\
\hline 25 & $\begin{array}{l}\text { Maxim } \\
\text { um }\end{array}$ & $\begin{array}{l}\text { Maxi } \\
\text { mum }\end{array}$ & $\begin{array}{l}\text { Mini } \\
\text { mum }\end{array}$ & & imum & $\begin{array}{l}\text { Mini } \\
\text { mu } \\
\text { m }\end{array}$ & $\begin{array}{l}\text { Minimu } \\
\mathrm{m}\end{array}$ \\
\hline 26 & $\begin{array}{l}\text { Maxim } \\
\text { um }\end{array}$ & $\begin{array}{l}\text { Maxi } \\
\text { mum }\end{array}$ & $\begin{array}{l}\text { Mini } \\
\text { mum }\end{array}$ & & imum & $\begin{array}{l}\text { Max } \\
\text { imu } \\
m\end{array}$ & $\begin{array}{l}\text { Minimu } \\
\mathrm{m}\end{array}$ \\
\hline 27 & $\begin{array}{l}\text { Maxim } \\
\text { um }\end{array}$ & $\begin{array}{l}\text { Maxi } \\
\text { mum }\end{array}$ & $\begin{array}{l}\text { Mini } \\
\text { mum }\end{array}$ & & ximum & $\begin{array}{l}\text { Mini } \\
\text { mu } \\
\text { m }\end{array}$ & $\begin{array}{l}\text { Minimu } \\
\mathrm{m}\end{array}$ \\
\hline 28 & $\begin{array}{l}\text { Maxim } \\
\text { um }\end{array}$ & $\begin{array}{l}\text { Maxi } \\
\text { mum }\end{array}$ & $\begin{array}{l}\text { Mini } \\
\text { mum }\end{array}$ & & kimum & $\begin{array}{l}\text { Max } \\
\text { imu } \\
\mathrm{m}\end{array}$ & $\begin{array}{l}\text { Minimu } \\
\mathrm{m}\end{array}$ \\
\hline
\end{tabular}

Published By:

IJITEE 


\begin{tabular}{|l|l|l|l|l|l|l|}
\hline S.No & $\begin{array}{l}\text { Traffic } \\
\text { Load } \\
\text { (L) }\end{array}$ & $\begin{array}{l}\text { Handover } \\
\text { Latency } \\
\text { (H) }\end{array}$ & $\begin{array}{l}\text { Battery } \\
\text { Power } \\
(\mathrm{P})\end{array}$ & $\begin{array}{l}\text { Secu } \\
\text { rity } \\
\text { (S) }\end{array}$ & $\begin{array}{l}\text { Probabili } \\
\text { ty to } \\
\text { Select } \\
\text { Target } \\
\text { Cell (TC) }\end{array}$ \\
\hline 29 & $\begin{array}{l}\text { Maxim } \\
\text { um }\end{array}$ & $\begin{array}{l}\text { Maxi } \\
\text { mum }\end{array}$ & $\begin{array}{l}\text { Maxi } \\
\text { mum }\end{array}$ & Minimum & $\begin{array}{l}\text { Mini } \\
\text { mu } \\
\mathrm{m}\end{array}$ & $\begin{array}{l}\text { Minimu } \\
\mathrm{m}\end{array}$ \\
\hline 30 & $\begin{array}{l}\text { Maxim } \\
\text { um }\end{array}$ & $\begin{array}{l}\text { Maxi } \\
\text { mum }\end{array}$ & $\begin{array}{l}\text { Maxi } \\
\text { mum }\end{array}$ & Minimum & $\begin{array}{l}\text { Max } \\
\text { imu } \\
\mathrm{m}\end{array}$ & $\begin{array}{l}\text { Minimu } \\
\mathrm{m}\end{array}$ \\
\hline 31 & $\begin{array}{l}\text { Maxim } \\
\text { um }\end{array}$ & $\begin{array}{l}\text { Maxi } \\
\text { mum }\end{array}$ & $\begin{array}{l}\text { Maxi } \\
\text { mum }\end{array}$ & Maximum & $\begin{array}{l}\text { Mini } \\
\text { mu } \\
\mathrm{m}\end{array}$ & $\begin{array}{l}\text { Minimu } \\
\mathrm{m}\end{array}$ \\
\hline 32 & $\begin{array}{l}\text { Maxim } \\
\text { um }\end{array}$ & $\begin{array}{l}\text { Maxi } \\
\text { mum }\end{array}$ & $\begin{array}{l}\text { Maxi } \\
\text { mum }\end{array}$ & Maximum & $\begin{array}{l}\text { Max } \\
\text { imu } \\
\mathrm{m}\end{array}$ & $\begin{array}{l}\text { Minimu } \\
\mathrm{m}\end{array}$ \\
\hline
\end{tabular}

\section{Defuzzification}

In this method, a crisp is returned from the output Fuzzy set. Among the various types of defuzzification methods, the centroid of area method is applied.

\section{RESULT AND DISCUSSION}

\section{A. Experimental Settings}

The proposed Fuzzy-Markov Model for Location Prediction (FMMLP) protocol is simulated in NS2 and compared with DHO protocol and the folMinimuming metrics are analyzed such as E2D, PDR, Overhead, Packets and Throughput.

Table III shows the experimental settings.

Table III: Experimental Settings

\begin{tabular}{|c|c|}
\hline Number of nodes & $18,36,54$ and 108 \\
\hline Topology Size & 1000 X 1000 \\
\hline MAC & 802.11 \\
\hline Total Simulation Time & $50 \mathrm{sec}$ \\
\hline Traffic Source & CBR \\
\hline Number Of Handoffs & $1,2,3,4$ and 5 \\
\hline Propagation Model & TwoRayGround \\
\hline Antenna Type & OmniAntenna \\
\hline Transmission Rate & $1 \mathrm{Mb}$ \\
\hline Packet Size & 500 bytes \\
\hline
\end{tabular}

\section{B. Varying the number of handoffs}

In this section, the results for varying the number of handoffs from 1 to 5 are presented.

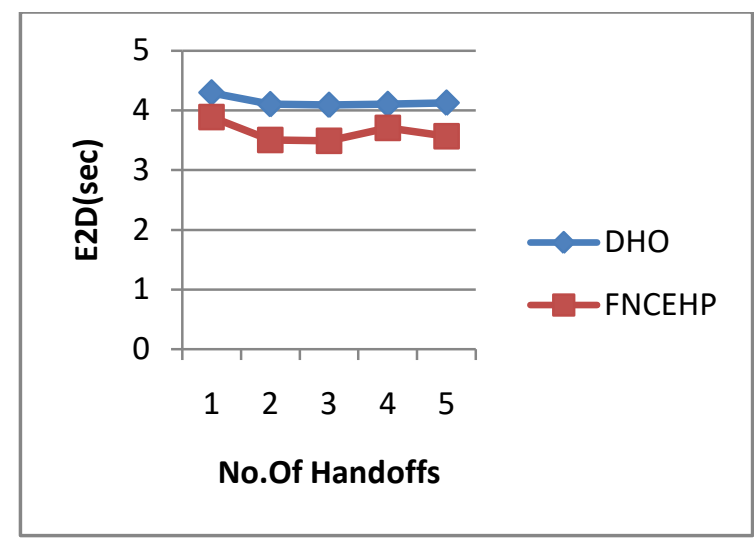

Fig. 8. E2D for varying handoffs

The result graph of E2D for different number of handoff is shown in Figure 8. It can be observed that the E2D of FNCEHP ranges from 3.8 to 3.5 seconds and the E2D of DHO ranges from 4.2 to 4.12 seconds. Ultimately, the E2D of FNCEHP has $12 \%$ lesser than DHO.

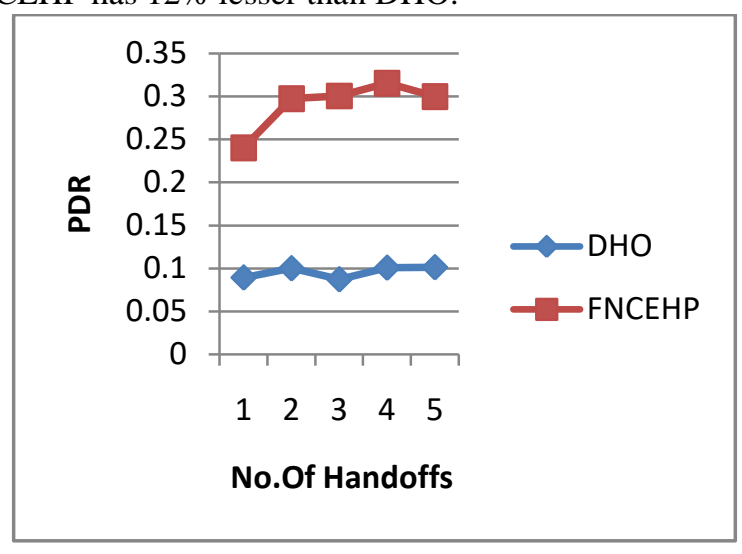

Fig 9. PDR for varying handoffs

The result graph of PDR for different number of handoff is shown in Figure 9. It can be observed that the PDR of FNCEHP ranges from 0.24 to 0.29 and the PDR of DHO ranges from 0.08 to 0.10 . Ultimately, the PDR of FNCEHP has $67 \%$ Maximumer than DHO.

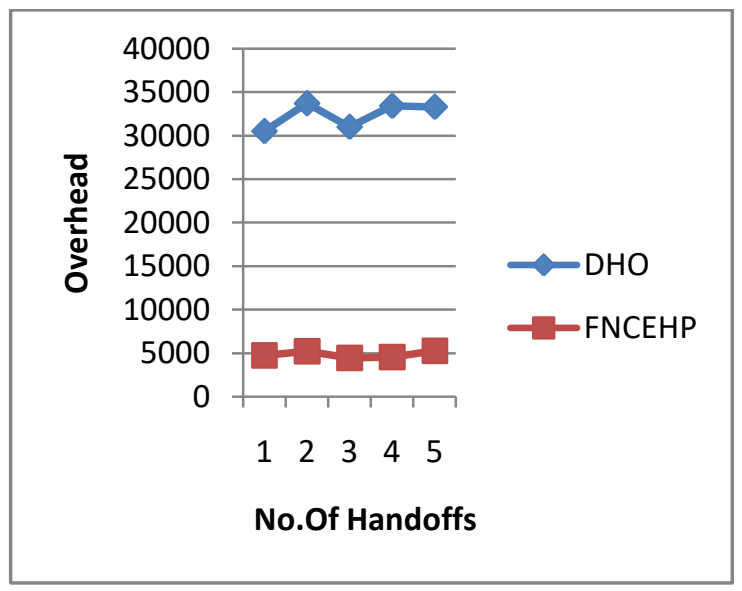

Fig .10. Overhead for varying handoffs 
The result graph of overhead for different number of handoff is shown in Figure 10. It can be observed that the overhead of FNCEHP ranges from 4714 to 5262 and the overhead of DHO ranges from 30478 to 33270 . Ultimately, the overhead of FNCEHP has $85 \%$ lesser than DHO.

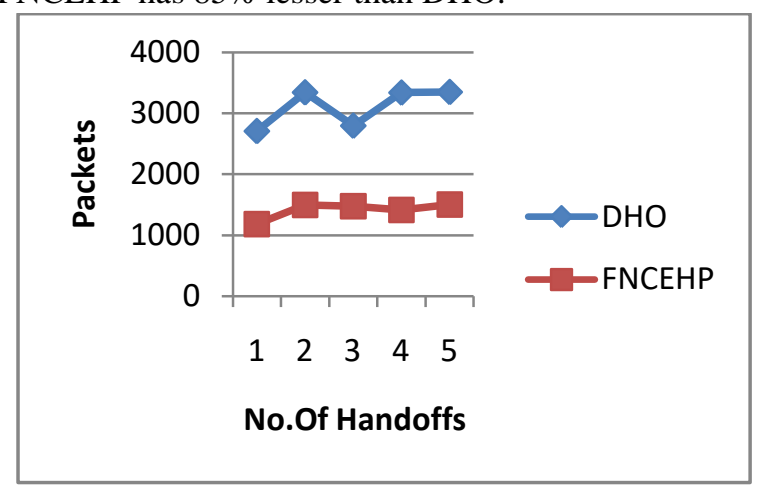

Fig. 11. Packets for varying Handoffs

The result graph of packets for different number of handoff is shown in Figure 11. It can be observed that the packets of FNCEHP ranges from 4714 to 5262 and the packets of DHO ranges from 30478 to 33270 . Ultimately, the packets of FNCEHP has $85 \%$ lesser than DHO.

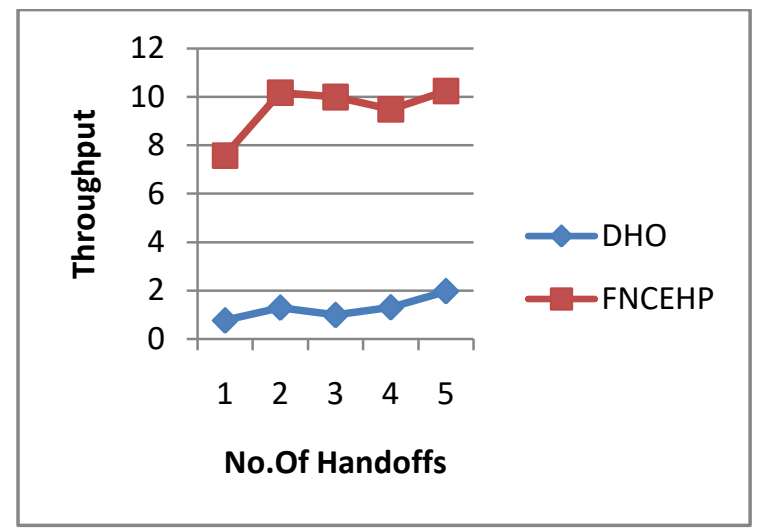

Fig 12. Throughput for varying Handoffs

The result graph of throughput for different number of handoff is shown in Figure 12. It can be observed that the throughput of FNCEHP ranges from 7.5 to 10.2 and the throughput of DHO ranges from 0.7 to 1.9 . Ultimately, the throughput of FNCEHP has $87 \%$ Maximumer than DHO.

C. Based on Nodes

In this section, the results for varying the number of nodes from 18 to 108 are presented

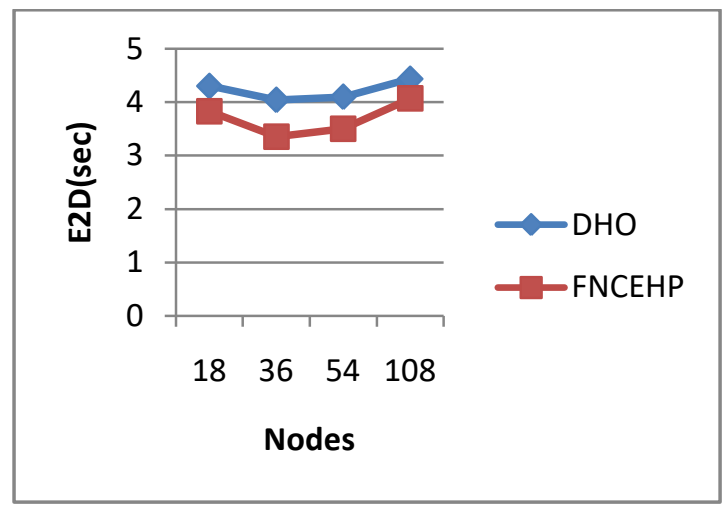

Fig. 13. E2D for varying Nodes
The result graph of E2D for different number of nodes is shown in Figure 13. It can be observed that the E2D of FNCEHP ranges from 3.8 to 4.0 seconds and the E2D of DHO ranges from 4.2 to 4.4 seconds. Ultimately, the E2D of FNCEHP has $13 \%$ lesser than DHO.

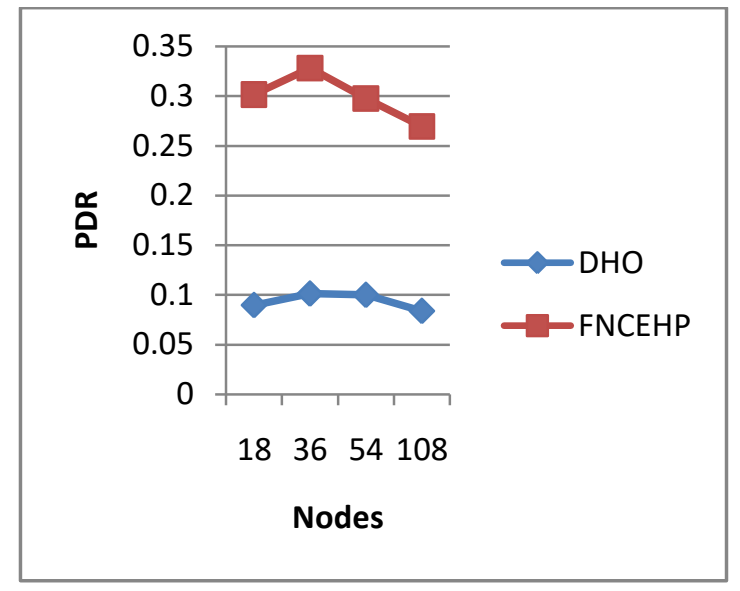

Fig.14. PDR for varying Nodes

The result graph of PDR for different number of nodes is shown in Figure 14. It can be observed that the PDR of FNCEHP ranges from 0.30 to 0.26 and the PDR of DHO ranges from 0.09 to 0.08 . Ultimately, the PDR of FNCEHP has $69 \%$ Maximumer than DHO.

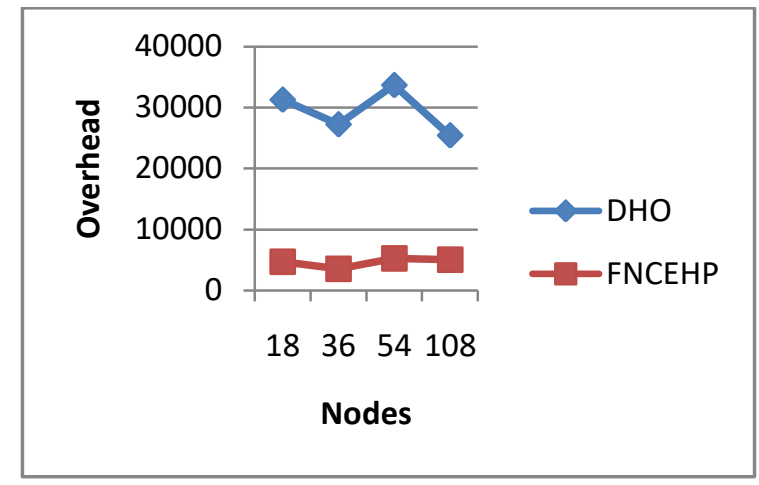

Fig.15. Overhead for varying Nodes

The result graph of overhead for different number of nodes is shown in Figure 15. It can be observed that the overhead of FNCEHP ranges from 4699 to 5023 and the overhead of DHO ranges from 31290 to 25436 . Ultimately, the overhead of FNCEHP has $84 \%$ lesser than DHO.

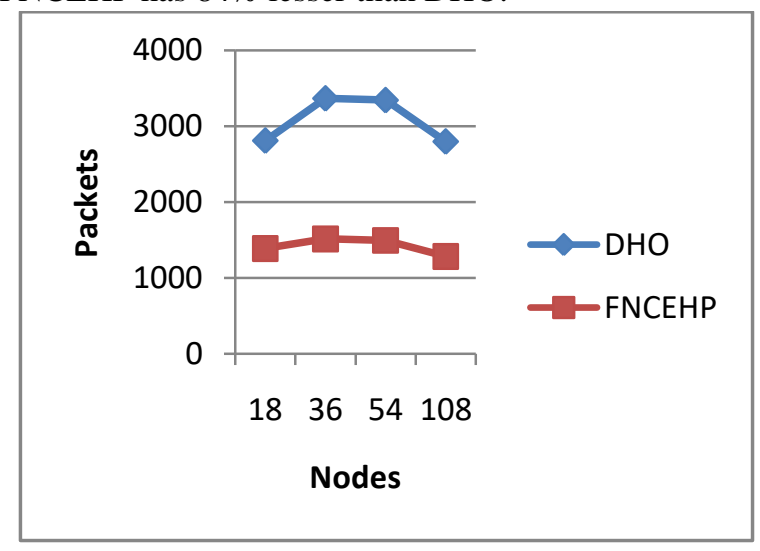

Fig 16. Packets for varying Nodes

Published By:

Blue Eyes Intelligence Engineering 
The result graph of packets for different number of nodes is shown in Figure 16. It can be observed that the packets of FNCEHP ranges from 1389 to 1284 and the packets of DHO ranges from 2810 to 2798 . Ultimately, the packets of FNCEHP has 54\% lesser than DHO.

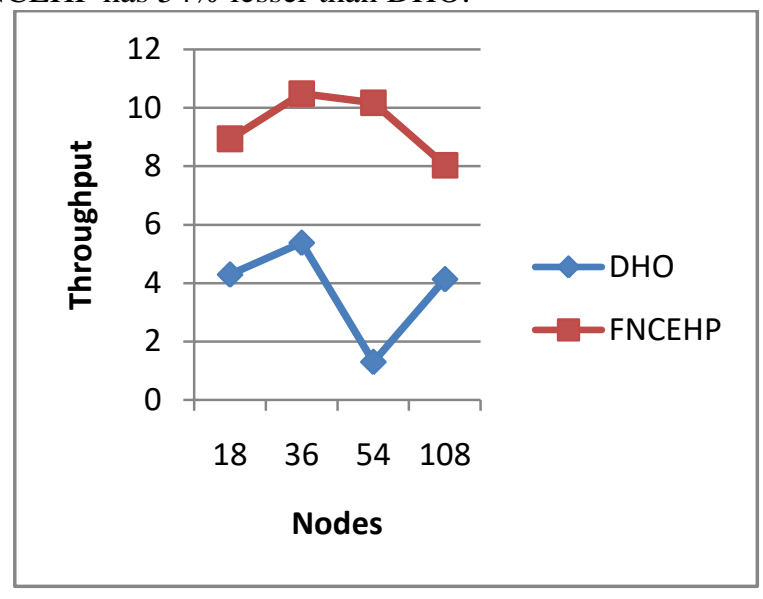

Fig .17. Throughput for varying Nodes

The result graph of throughput for different number of nodes is shown in Figure 17. It can be observed that the throughput of FNCEHP ranges from 8.9 to 8.0 and the throughput of DHO ranges from 4.2 to 4.1. Ultimately, the throughput of FNCEHP has 59\% Maximumer than DHO.

\section{CONCLUSION}

In this paper, we have designed handoff prediction and target network selection scheme for 5G-IoT networks. For VHO triggering condition, Multi-layer Feed Forward Network (MFNN) is applied which will predict the user mobility based on distance, RSS, mobile speed and direction parameters. For target cell selection, Fuzzy decision model is applied based on the network level metrics such as traffic load, handover latency, battery power and user level metrics such as security and cost. The proposed approach has been implemented in NS3 and the performance is measured in terms of network throughput, handoff delay, handoff cost and prediction

\section{REFRENCES:}

1. A. Suresh Kumar, S. Vanmathi, B. Praveen Sanjay, S. Ramya Bharathi and M. Sakthi Meena, "Handover forecasting in $5 \mathrm{G}$ using machine learning",International Journal of Engineering \& Technology, 7 (2.31) (2018) 76-79,2018

2. Fan Jia and Xiaolin Zheng, "A Request-Based Handover Strategy Using NDN for 5G",Wireless Communications and Mobile Computing,Volume 2018, Article ID 4513070, 9 pages,2018.

3. Le Luong Vy, Li-Ping Tung and Bao-Shuh Paul Lin, "Big Data and Machine Learning Driven Handover Management and Forecasting",IEEE Conference on Standards for Communications and Networking (CSCN),2017.

4. BRIAN ORYEMA,SEUNGMAN CHUN and JONGTAE PARK, "A MOBILITY MANAGEMENT ARCHITECTURE FOR INTERNET OF THINGS USING COAP",International Journal Of Electrical, Electronics And Data Communication, ISSN: 2320-2084 Volume-5, Issue-1,2017.

5. Vijaya Yajnanarayana, Henrik Ryden, L aszl o H evizi, Ankit Jauhari and Mirsad Cirkic Ericsson, "5G Handover using Reinforcement Learning",CoRR abs/1904.02572,2019.

6. Miran Taha, Lorena Parra, Laura Garcia and Jaime Lloret, "An Intelligent handover process algorithm in $5 \mathrm{G}$ networks: The use case of mobile cameras for environmental surveillance",WT04-5thIEEE International Workshop on Smart Communication Protocols and Algorithms (SCPA 2017),2017.
7. Metin Ozturk, Mandar Gogate, Oluwakayode Onireti, Ahsan Adeel Amir Hussain and Muhammad A. Imran, "A novel deep learning driven, Minimum-cost mobility prediction approach for $5 \mathrm{G}$ cellular networks: The case of the Control/Data Separation Architecture (CDSA)", Elsevier,Neurocomputing 358 (2019) 479-489,2019.

8. Po-Chiang Lin, Lionel F. Gonzalez Casanova, and Bakary K. S. Fatty, "Data-Driven Handover Optimization in Next Generation Mobile Communication Networks",Hindawi Publishing Corporation,Mobile Information Systems, Volume 2016, Article ID 2368427, 11 pages, 2016 .

9. Nawaporn Wisitpongphan, Watchareewan Jitsakul, and Duangporn Jieamumporn, "Travel Time Prediction using Multi-Layer Feed Forward Artificial Neural Network", IEEE Fourth International Conference on Computational Intelligence, Communication Systems and Networks, 2012

10. Daniel Svozil, Vladimir KvasniEka and JiE Pospichal, "Introduction to multi-layer feed-forward neural network", Chemometrics and Intelligent Laboratory Systems 39 (1997) 43-62

11. NerMinimum Makhlouf," Exploiting Neural Networks for Mobility Prediction in Mobile Ad Hoc Networks', VOL.18, NO.3, JUNE 2016

12. Karthik Vasudeva, Sener Dikmese, 'Ismail G"uvenc, Abolfazl Mehbodniya, Walid Saad and Fumiyuki Adachi,"Fuzzy Logic Game-Theoretic Approach for Energy Efficient Operation in HetNets", WS05-International Workshop on Application of green techniques to emerging communication and computing paradigms (GCC)

13. Murad Khan, Awais Ahmad, Shehzad Khalid, Syed Hassan Ahmed, Sohail Jabbar and Jamil Ahmad, "Fuzzy based multi-criteria vertical handover decision modelling in heterogeneous wireless networks", Multimed Tools Appl (2017) 76:24649-24674

\section{AUTHORS PROFILE}

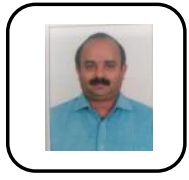

RASHAD T.S received his B.Tech degree in Electronics and Communication Engineering from Calicu University, Kerala, M.S from Manipal University in the field of Micro-Electronics and pursuing Ph.D. in Dept. of ECE from GITAM deemed to be University, Visakhapatnam.

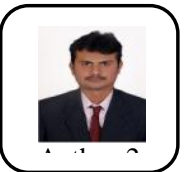

A.Ch.Sudhir received M.Tech degree in ECE from Andhra University, Visakhapatnam PGDES fromUniversity of Hyderabad,MBA fromAcharya Nagarjuna University and $\mathrm{Ph} . \mathrm{D}$ in Wireless communication from JNTUK , kakinada. He has 14 years of teaching experience and presently working as Assistant Professor in Dept. ECE, GITAM deemed to be University,Visakhapatnam. He has almost 25 technical papers published in reputed journals and conferences. His research interests include Wireless communication and networks, Embedded systems, Optical fiber communication and Internet of things application messaging protocols. 